trans-Alpine and Western Europe, 1400-400 B.C.; Miss P. M. Kemp (formerly lecturer, University of Allahabad), household economy and technology of some tribal communities in the Punjab; Dr. P. F. R. Venables (principal, Royal Technical College, Salford), training schemes in certain industries, with special reference to the work of technical colleges and the needs of smaller firms. Research Grants : Dr. R. Common (lecturer in the Department of Geography, University of Glasgow), the geomorphology of the lower Vardar and Aliakmon valleys, Greece; Dr. Florence N. David (reader in statisties, University College, London), the history of probability and statistics ; L. W. Derry (head of the Department of Metallurgy, Battersea Polytechnic, London) and E. W. Wilkins (Royal Aeronautical Society), a statistical investigation into the fatigue properties of certain non-ferrous metals; P. M. Fraser (Fellow of All Souls College, Oxford), a corpus of Ptolemaic inscriptions; Dr. O. R. Gurney (Shillito reader in Assyriology, University of Oxford), the Assyrian literary tablets from Sultantepe now in Ankara; Dr. V.H. Heywood (systematic botanist), a botanical investigation of the mountainous zones of south-east Spain; P. A. D. Hollom (accountant), distribution of field characters of birds of the eastern Mediterranean region; S. H. F. Lloyd (director, British Institute of Archæology, Ankara), Beycesultan excavations-a supposed centre of late Bronze Age civilization in non-Hittite Anatolia; Dr. A. G. Lowndes (schoolmaster, Plymouth College), tracer minerals and deep-water drift in the western approaches to the English Channel ; Dr. A. Lamont (geologist and journalist), faunas of cherts in the southern uplands of Scotland; Miss R. L. B. Moss (editor, Topographical Bibliography), ancient Egyptian inscribed and sculptured objects in Russian museums ; Dr. F. J. North (keeper, Department of Geology, National Museum of Wales, Cardiff), a biography of Sir H. T. de la Beche, founder of the Geological Museum ; Dr. H. Scott (formerly assistant keeper, Department of Entomology, British Museum (Natural History)), biogeographical research at high altitudes in south and south-eastern Ethiopia; Dr. Marjorie M. Sweeting (tutor in geography, St. Hugh's College, Oxford), physiographical investigations in the 'Cockpit Country' of Jamaica; A. Young (lecturer in the Department of Applied Mathematies, University of Liverpool), analysis of observations of the variation of latitude.

\section{Commonwealth Fund Fellowships}

THE Committee of Award of the Commonwealth Fund Fellowships announces the following elections, among others, for 1955-56: General Fellowships: M. F. Atiyah, Trinity College, Cambridgo (mathematics); A. O. Betts, Royal Veterinary College, London, and Cambridge (veterinary science); D. J. Candlin, Trinity College, Cambridge, and Birmingham (physies); M. A. E. Dummett, All Souls College, Oxford (philosophy); H. M. Frey, Balliol College, Oxford (chemistry); K. W. Gruenberg, Magdalene College, Cambridge, and Queen Mary College, London (mathematics); C.W. MoCombie, Aberdeen (physics); A. R. Muir, Edinburgh (medicine); J. C. Polkinghorne, Trinity College, Cambridge (physics); A. P. Ryle, Trinity College, Cambridge (biochemistry); K. E. Snelson, Trinity College, Cambridge (engineering) ; J. H. Williamson, Edinburgh, Christ's College, Cambridge, and Queen's University, Belfast (mathematics) ; D. G. Wilson, Birmingham and Nottingham (chemical engineering); P. D. Wood, Aberystwyth and Reading (geography); Home Civil Service Fellowships: W. J. Bray (Post Office Engineering Department) ; F. Caunce (Ministry of Education); A. W. Peterson (Home Office) ; H. P. Rowe (Treasury); J. Seddon (Ministry of Supply); Colonial Civil Service Fellowships : M. F. H. Abraham (Kenya); J. H. Alman (North Borneo).

\section{University of Birmingham}

Prof. T. U. Matthew, Luces professor of engin. eering production in the University of Birmingham, is resigning from his chair on appointment to a post with Tube Investments, Ltd. The following have been appointed lecturers in the University: $\mathbf{H}$. Gilmour (petroleum production engineering) and Dr. A. Sagarra (chemical engineering). The title of University Research Fellow has been given to the following during the tenure of their present posts. Physics: Dr. J. C. Bower (senior lecturer in physics, University of Melbourne); Prof. G. Martelli (Pisa); Dr. K. K. Damodaran, Dr. S. J. Goldsack and Dr. M. M. Winn (Department of Scientific and Industrial Research). Chemistry: Dr. J. R. Urwin (lecturer in chemistry, University of Adelaide); Dr. H. Weigel (Aachen). Experimental Pathology: Dr. D. R. Stanworth and Dr. S. T. C. Wright.

National Research Council, Canada : Members

THE following have been appointed new members of the National Research Council, Canada, for three years from April 1 : Dr. R. S. Jane, executive vicepresident, Shawinigan Chemicals, Ltd., Montreal ; and Dr. H. G. Thode, principal of Hamilton College and director of research at McMaster University, Hamilton, Ontario. Three other members of the Council have been reappointed for a further term of three years: Dr. C. J. Mackenzie, president of the Atomic Fnergy Control Board, Ottawa; Dr. T. Thorvaldson, emeritus dean of graduate studies, University of Saskatchewan, Saskatoon ; and Dr. W. H. Watson, professor and head of the Department of Physics, University of Toronto.

\section{Royal Society of South Africa : Council}

THe Council for 1955 of the Royal Society of South Africa has been elected as follows : President, S. H. Haughton; Honorary General Secretary, W. J. Talbot; Honorary Treasurer, N. Sapeika; Acting Honorary Editor of Transactions, A. M. Talbot; Honorary Librarian, E. Newbery ; Other Members of Council, H. B. S. Cooke, W. J. Copenhagen, J. H. Day, R. Elsdon-Dew, C. van Riet Lowe, S. M. Naudé, S. H. Skaife and J. L. B. Smith.

\section{American Academy of Arts and Sciences}

The following have been elected officers for the year 1955-56 of the American Academy of Arts and Sciences: President, J. E. Burchard; Vice-President of Class I (Mathematical and Physical Sciences), E. L. Bowles; Vice-President of Class II (Biological Sciences), H. Hoagland; Vice-President of Class III (Social Arts and Sciences), D. F. Edwards; VicePresident of Class IV (Humanities), R. Ulich; Secretary, W. C. Greene; Treasurer, T. B. Adams; Editor and Librarian, W. M. Whitehill. The following have been elected, among others, foreign honorary members of the Academy : Class I, Prof. A. C. B. Lovell, professor of radio astronomy in the University of Manchester; Class II, Dr. J. A. M. Runnström, of the Wenner-Grens Institute for Experimental Biology, Stockholm. 